\title{
Protein timing and its effects on muscular hypertrophy and strength in individuals engaged in weight-training
}

\author{
Matthew Stark ${ }^{1}$, Judith Lukaszuk ${ }^{1 *}$, Aimee Prawitz ${ }^{1}$ and Amanda Salacinski ${ }^{2}$
}

\begin{abstract}
The purpose of this review was to determine whether past research provides conclusive evidence about the effects of type and timing of ingestion of specific sources of protein by those engaged in resistance weight training. Two essential, nutrition-related, tenets need to be followed by weightlifters to maximize muscle hypertrophy: the consumption of 1.2-2.0 g protein. $\mathrm{kg}^{-1}$ of body weight, and $\geq 44-50 \mathrm{kcal}^{\mathrm{kg}} \mathrm{g}^{-1}$ of body weight. Researchers have tested the effects of timing of protein supplement ingestion on various physical changes in weightlifters. In general, protein supplementation pre- and post-workout increases physical performance, training session recovery, lean body mass, muscle hypertrophy, and strength. Specific gains, differ however based on protein type and amounts. Studies on timing of consumption of milk have indicated that fat-free milk post-workout was effective in promoting increases in lean body mass, strength, muscle hypertrophy and decreases in body fat. The leucine content of a protein source has an impact on protein synthesis, and affects muscle hypertrophy. Consumption of 3-4 g of leucine is needed to promote maximum protein synthesis. An ideal supplement following resistance exercise should contain whey protein that provides at least $3 \mathrm{~g}$ of leucine per serving. A combination of a fast-acting carbohydrate source such as maltodextrin or glucose should be consumed with the protein source, as leucine cannot modulate protein synthesis as effectively without the presence of insulin. Such a supplement post-workout would be most effective in increasing muscle protein synthesis, resulting in greater muscle hypertrophy and strength. In contrast, the consumption of essential amino acids and dextrose appears to be most effective at evoking protein synthesis prior to rather than following resistance exercise. To further enhance muscle hypertrophy and strength, a resistance weight- training program of at least 10-12 weeks with compound movements for both upper and lower body exercises should be followed.
\end{abstract}

Keywords: Protein timing, Muscular hypertrophy, Muscular strength, Body composition, Whey protein, Milk protein, Protein synthesis

\section{Review}

Purpose

Individuals who engage in resistance weight training, whether as competitive weightlifters or to promote optimal physical outcomes, would benefit by knowing the ideal nutritional intake protocol needed to maximize muscle hypertrophy and strength. The type, timing (pre/ post workout) or amount of protein intake required to meet strength-training goals may not be clear to

\footnotetext{
* Correspondence: jmlukaszuk@niu.edu

${ }^{1}$ School of Family, Consumer, and Nutrition Sciences. Northern Illinois University, DeKalb, IL, USA

Full list of author information is available at the end of the article
}

weightlifters or their trainers. The purpose of this review was to determine whether past research provides conclusive evidence about the effects of type and timing of ingesting specific protein sources by those engaged in resistance weight training. The review targets the effects of intake and timing of the following protein sources on physical outcomes: whey, casein, milk, soy and essential amino acids.

\section{Protein and calorie intake}

For maximal muscle hypertrophy to occur, weightlifters need to consume 1.2-2.0 grams (g). protein kilogram. $(\mathrm{kg})^{-1}$ and > 44-50 kilocalories $(\mathrm{kcal}) \mathrm{kg}^{-1}$ body weight

\section{Ciomed Central}


daily [1-9]. This is considerably higher than the recommended dietary allowance (RDA) for protein (currently $0.8 \mathrm{~g} \mathrm{~kg}^{-1}$ ) which meets the needs of $97.5 \%$ of all healthy adult Americans not engaged in weightlifting with the intent of gaining muscle mass [8]. Table 1 summarizes ranges for protein intake for weightlifters based on previous literature reviews.

\section{Leucine and muscle protein synthesis}

The leucine content of a protein source has an impact on protein synthesis, and affects muscle hypertrophy [10-15]. This section details the role of leucine in protein synthesis to illustrate its importance in the process.

Protein synthesis occurs when methionyl-transfer ribonucleic acid (methionyl-tRNA) binds to a eukaryotic small ribosomal subunit ( $40 \mathrm{~S}$ ribosomal unit) resulting in the formation of a pre-initiation complex (43S preinitiation complex) [16]. This initial step is mediated by eukaryotic initiation factor 2 (eIF2) [16]. The 43S complex subsequently binds to messenger ribonucleic acid (mRNA) near the cap structure. After successful engagement of the $43 \mathrm{~S}$ pre-initiation complex to RNA, the molecule eukaryotic initiation factor 5 (eIF5) removes eIF2 while a molecule of guanosine triphospahte (GTP) is hydrolyzed so that eIF2 is recycled to its active form of eIF2-GTP [16]. This allows eIF2-GTP to continue with the initial step of protein synthesis. Once eIF2-GTP is released, the second step can occur. A ribosomal binding site/translation start site forms once eukaryotic initiation factor $4 \mathrm{~F}$ (eIF4F) recognizes the molecule [16]. The eIF4F complex binds the eukaryotic initiation factor 4E (eIF4E) subunit of eIF4F to the $\mathrm{m}^{7} \mathrm{GTP}$ cap structure present in all eukaryotic mRNAs [16]. Replication of the mRNA strand occurs, thus indicating protein synthesis. The processes of protein synthesis appear to be highly regulated by the amino acid leucine [10-14].

Leucine plays a role in muscle protein synthesis mostly through stimulation of the mammalian target of rapamaycin (mTOR) signaling pathway $[15,17,18]$. Leucine interacts with two mTOR regulatory proteins, mTOR raptor (or raptor) and rashomolog enriched in the brain (or Rheb) $[19,20]$. The importance of the regulation of mTOR is that when activated, it phosphorylates the proteins eIF4E binding protein 1 (4E-BP1) and ribosomal protein S6 kinase (S6K1) complex [21,22]. When 4E-BP1 is phosphorylated, it becomes inactive, which allows the continuation of the second step initiation phase of translation by inhibiting its binding to eIF4F complex [10]. This allows additional translation to occur. When S6K1 is phosphorylated, it produces additional eIFs which increases the translation of mRNAs that encode components of the protein synthesis pathway $[10,12]$.

Leucine has been indicated as the sole stimulator of protein synthesis [10-15]. For example, Dreyer et al. conducted a study on 16 young, healthy untrained men to determine the effects of post-workout consumption of either no beverage or leucine-enhanced EAAs [15]. Those consuming the leucine-enhanced beverage one hour following a single bout of resistance exercise had greater rates of protein synthesis than did the control group. Another study conducted by Koopman et al. [23] concurs with the findings of Dreyer. Eight untrained men were randomly assigned to consume one of the three beverages: carbohydrates, carbohydrate and protein or carbohydrate, protein and free leucine following 45 minutes of resistance exercise. The results indicated that whole body net protein balance was significantly greater in the carbohydrate, protein and leucine group compared with values observed in the carbohydrate and protein and carbohydrate only groups, indicating the ability of leucine to augment protein synthesis [23].

Leucine alone appears to be nearly as effective in stimulating protein synthesis as when all branched chain amino acids (BCAAs) are consumed [24-26]. Leucine also seems to have both insulin-dependent and insulinindependent mechanisms for promoting protein synthesis $[27,28]$. Approximately 3 to $4 \mathrm{~g}$ of leucine per serving is needed to promote maximal protein synthesis $[29,30]$. See Table 2 for the leucine content of protein sources for all protein ingestion timing studies referenced in this review.

\section{Types of protein}

There are numerous protein sources available to the consumer. This review article focuses on studies that

Table 1 Summary of protein requirements for weightlifters

\begin{tabular}{llr}
\hline Research study & Recommendation for protein intake & Type of study \\
\hline Lemon [1] & $1.6-1.7 \mathrm{~g} \mathrm{~kg}^{-1}$ & Review of literature \\
\hline Lemon et al. [2] & $12-15 \%$ total energy intake & Review of literature \\
\hline Kreider [3] & $1.3-1.8 \mathrm{~g} \mathrm{~kg}^{-1}$ & Review of literature \\
\hline Phillips [4] & $12-15 \%$ total energy intake & Review of literature \\
\hline Lemon [5] & $1.6-1.8 \mathrm{~g} \mathrm{~kg}^{-1}$ & Review of literature \\
\hline Lemon [6] & $1.5-2.0 \mathrm{~g} \mathrm{~kg}^{-1}$ & Review of literature \\
\hline Campbell et al. [7] & $1.4-2.0 \mathrm{~g} \mathrm{~kg}^{-1}$ & Review of literature \\
\hline
\end{tabular}


Table 2 Leucine content of protein sources for studies that used a protein ingestion timing method

\begin{tabular}{|c|c|c|c|}
\hline $\begin{array}{l}\text { Research } \\
\text { study }\end{array}$ & Protein used & $\begin{array}{l}\text { Leucine } \\
\text { content }\end{array}$ & $\begin{array}{l}\text { Reached } 3 g \\
\text { Threshold for Leucine }\end{array}$ \\
\hline $\begin{array}{l}\text { Hoffman } \\
\text { et al. [31] }\end{array}$ & $\begin{array}{l}42 \mathrm{~g} \text { of a proprietary blend of protein (enzymatically hydrolyzed collagen protein isolate, } \\
\text { whey protein isolate, and casein protein isolate) }\end{array}$ & $3.6 \mathrm{~g}$ & Yes \\
\hline $\begin{array}{l}\text { Hoffman } \\
\text { et al. [32] }\end{array}$ & $\begin{array}{l}42 \mathrm{~g} \text { of a proprietary protein blend (enzymatically hydrolyzed collagen protein isolate, whey } \\
\text { protein isolate, casein protein isolate, plus } 250 \mathrm{mg} \text { of additional branch chain amino acids) }\end{array}$ & $3.6 \mathrm{~g}$ & Yes \\
\hline $\begin{array}{l}\text { Cribb et al. } \\
\text { [33] }\end{array}$ & Whey protein, creatine and dextrose mixture based on individuals bodyweight & $3.49 \mathrm{~g}^{1}$ & Yes \\
\hline $\begin{array}{l}\text { Verdijk et al. } \\
\text { [34] }\end{array}$ & $20 \mathrm{~g}$ of casein split into two $10 \mathrm{~g}$ servings pre- and post-workout & $\begin{array}{l}1.64 \mathrm{~g} \text { total in } 2 \\
\text { servings }^{2}\end{array}$ & No \\
\hline $\begin{array}{l}\text { Hulmi et al. } \\
{[35]}\end{array}$ & $30 \mathrm{~g}$ whey split into two $15 \mathrm{~g}$ servings pre- and post-workout & $\begin{array}{l}3.4 \mathrm{~g} \text { total in } 2 \\
\text { servings }\end{array}$ & $\begin{array}{l}\text { No as only } 1.7 \mathrm{~g} \text { were } \\
\text { given at a time }\end{array}$ \\
\hline $\begin{array}{l}\text { Andersen } \\
\text { et al. [36] }\end{array}$ & $\begin{array}{l}25 \mathrm{~g} \text { of a protein blend ( } 16.6 \mathrm{~g} \text { of whey protein; } 2.8 \mathrm{~g} \text { of casein; } 2.8 \mathrm{~g} \text { of egg white protein; } \\
\text { and } 2.8 \mathrm{~g} \text { of I-glutamine) }\end{array}$ & $2.29 \mathrm{~g}^{2,3}$ & No \\
\hline $\begin{array}{l}\text { Elliot et al. } \\
\text { [37] }\end{array}$ & $237 \mathrm{~g}$ of whole milk & $0.639 \mathrm{~g}$ & No \\
\hline $\begin{array}{l}\text { Hartman } \\
\text { et al. [38] }\end{array}$ & $500 \mathrm{~mL}$ of fat-free milk & $1.35 \mathrm{~g}$ & No \\
\hline $\begin{array}{l}\text { Wilkinson } \\
\text { et al. [39] }\end{array}$ & $500 \mathrm{~mL}$ of fat-free milk & $1.35 \mathrm{~g}$ & No \\
\hline $\begin{array}{l}\text { Rankin et al. } \\
{[40]}\end{array}$ & Chocolate milk based on bodyweight & Unknown & Unknown \\
\hline $\begin{array}{l}\text { Josse et al. } \\
{[41]}\end{array}$ & $500 \mathrm{~mL}$ of fat-free milk & $1.35 \mathrm{~g}$ & No \\
\hline
\end{tabular}

${ }^{1} 3.49 \mathrm{~g}$ is based on the amount of leucine that the mean weight $(80 \mathrm{~kg})$ of the participants in this study.

${ }^{2}$ Leucine content of casein received from Tang et al. [42].

${ }^{3}$ Leucine content of egg white received from Norton et al. [43].

have used a variety of dairy- and soy-based protein sources. This section describes each of these protein sources and compares their quality on the two scales most relevant to this review: biological value and protein digestibility corrected amino acid score (PDCAAS) [44]. Biological value (BV), determines how efficiently exogenous protein leads to protein synthesis in body tissues once absorbed, and has a maximum score of 100 [44]. PDCAAS numerically ranks protein sources based on the completeness of their essential amino acid content, and has a maximum score of 1.0 [44]. The BV and PDCAAS are both important in understanding bioavailability and quality of different protein sources.

Three sources of dairy protein typically used in studies of muscle hypertrophy and strength are bovine milk, casein and whey. Bovine milk is a highly bioavailable source of protein, comprising $80 \%$ casein and $20 \%$ whey [44]. Overall, bovine milk has a BV of 91 and a PDCAAS of 1.00 indicating that it is readily absorbed by the body, promoting protein synthesis and tissue repair, and provides all essential amino acids (EAAs). Casein, with a BV of 77 and a PDCAAS of 1.00, is the predominate protein in bovine milk and gives milk its white color [44]. It exists in micelle form, and within the stomach will gel or clot, thus resulting in a sustained release of amino acids [45]. Compared with milk, it is less bioavailable, but like milk, it provides all EAAs. Whey the other protein found in milk, is the liquid part of milk that remains after the process of cheese manufacturing [44]. With a BV of 104 and a PDCAAS of 1.00, whey is superior to both milk and casein. It contains all EAAs, and its excellent bioavailability leads to rapid protein synthesis $[44,45]$.

Soy is a vegetable-based protein source that is useful for vegetarians and individuals who are lactose- or casein-intolerant. Soy has a BV of 74 and PDCAAS of 1.00 , indicating that it is not as bioavailable as milk based protein, but does contain all EAAs [44].

\section{Whole-food protein intake studies: post workout only}

The timing of protein intake has been an important condition in studies on muscle hypertrophy and strength in weight-trained individuals. In this section, studies using whole-food protein sources (i.e. bovine and soy milk) have been reviewed with respect to their intake following weight-resistance training.

Many studies on the effects of protein intake timing on physical changes have used protein supplements [31-36], but some studies have used milk and other fluid protein sources. In a study focused on protein intake following a single resistance training session, Elliot et al. examined milk consumption post-workout in 24 untrained men and women [37]. Subjects were randomly assigned to one of three groups: $237 \mathrm{~g}$ of fat-free milk, 
$237 \mathrm{~g}$ of whole milk, or $393 \mathrm{~g}$ of isocaloric fat-free milk. The findings indicated that in untrained individuals, threonine uptake was significantly higher for those consuming $237 \mathrm{~g}$ whole milk versus those consuming $237 \mathrm{~g}$ fat free milk. Threonine uptake is indicative of net muscle protein synthesis. The results of this study suggest that whole milk increased utilization of available amino acids for protein synthesis [37]. Tipton et al. conducted a study on 23 untrained men and women in which participants ingested 1) $20 \mathrm{~g}$ casein, 2) $20 \mathrm{~g}$ whey, or 3 ) artificially sweetened water one hour following heavy leg resistance exercise [46] Positive changes in net muscle protein balance resulted for both protein groups but not for the control group. This study indicated that milk proteins (both casein and whey) post-workout increased protein synthesis [46].

Various studies have compared whole-food protein sources to determine which is most effective in improving muscle mass and strength gains. Hartman et al. conducted a study comparing the use of milk, soy protein, or carbohydrate drinks by 56 young untrained males [38]. Subjects were assigned to one of three groups; each consumed 500-milliliter (mL) of a) fat-free milk, b) an isocaloric, isonitrogenous, and macronutrient- matched soy-protein beverage, or c) an isocaloric carbohydrate beverage immediately following and again one hour after resistance exercise. Body composition, muscle hypertrophy, and strength measurements were recorded at baseline and three days following 12 weeks of training 5 d.wk ${ }^{-1}$. The group using milk post-workout had significantly increased body weight and decreased body fat versus the other two groups, indicating an increase in lean body mass (LBM). Results indicated that consumption of fat-free milk post-workout was statistically more effective than soy protein in promoting increases in LBM $(\mathrm{p}<0.01)$, increases in type II muscle fiber area $(\mathrm{p}<0.05)$ and decreases in body fat $(\mathrm{p}<0.05)$ [38]. These results were similar to those found by Wilkinson et al. [39]. Researchers assigned eight weight-trained men to either $500 \mathrm{~mL}$ of skim milk or an isonitrogenous, isocaloric, and macronutrient-matched soy-protein beverage following resistance exercise [39]. A crossover design was used so that all participants consumed either milk or soy on their first trials and alternated to the other supplement on the second trials. Trials were separated by one week. Both protein drinks increased protein synthesis and promoted increases in muscle mass; however, the consumption of skim milk had a significantly greater impact on the development of muscle mass than did consumption of the soy protein [39]. Both Hartman et al. [38] and Wilkinson et al. [39] demonstrated the superiority of milk proteins over soy protein in building muscle mass. This may be due to the fact that soy has a lower BV than milk (74 versus 91 respectively), resulting in lower bioavailability, thus providing less protein synthesis in body tissues.

Rankin et al. studied the effects of milk versus carbohydrate consumption post-resistance exercise on body composition and strength [40]. Nineteen untrained men were randomly assigned to one of two groups that provided $5 \mathrm{kcal} \mathrm{kg}^{-1}$ body weight of either chocolate milk, or a carbohydrate-electrolyte beverage. Subjects completed whole body dual-energy X-ray absorptiometry (DXA) scans and strength assessments prior to and after following a $3 \mathrm{~d} \mathrm{wk}^{-1}$ for 10 -weeks weightlifting protocol. Results indicated that both groups had increases in LBM and strength, but there were no significant betweengroup differences [40]. The addition of a control group to this study would have helped determine whether increases in strength were due solely to the weightlifting program or to the combination of exercise and supplementation. The findings suggest that consumption of chocolate milk post-exercise may be effective in increasing LBM in weightlifters, but more studies using control groups are needed.

Milk consumption and resistance training also have been investigated in women. Josse et al. examined the effects of milk consumption post-workout on strength and body composition in 20 healthy untrained women [41]. Subjects were assigned to $500 \mathrm{~mL}$ of either fat-free milk or isocaloric maltodextrin. The women followed a weight training protocol $5 \mathrm{~d} \mathrm{wk}^{-1}$ for 12 -weeks. Each participant completed strength assessments, DXA scans, and blood tests. The group consuming milk had statistically greater increases in LBM, greater fat mass losses and greater gains in strength, providing evidence that fat-free milk consumption post-workout was effective in promoting increased LBM and strength in women weightlifters [41]. The results of this study support those of previous studies completed in men showing that milk consumption post-workout has a favorable effect on MPS [37-40].

\section{Protein supplement intake studies: a comparison of timing protocols}

Protein and amino acid supplements have been used widely in studies showing their effectiveness on protein synthesis. Hoffman et al. compared protocols providing protein supplementation and subsequent effects on muscle strength and body composition in 33 strengthtrained adult men [31]. Two protein-intake timing strategies were implemented over the course of 10-weeks of resistance weight-training [31]. One group consumed a protein supplement comprising enzymatically hydrolyzed collagen-, whey-, and casein-protein isolates pre/ post-workout. A second group consumed the same supplement in the morning upon awakening and in the evening. A control group was not given the protein 
blend. The average caloric intake of the three groups was $29.1 \pm 9.7 \mathrm{kcal} \cdot \mathrm{kg}$ body mass- ${ }^{1} \cdot \mathrm{d}^{-1}$.

Muscle strength was assessed through one-repetition maximum (1RM) on bench and leg press. Body composition was assessed using DXA [31]. There were no group differences in body composition based on timing of supplementation [31]. All groups increased the 1RM for squats, indicating increased muscle strength. Only the protein supplement groups also showed significant increases in the 1RM for bench press, indicating improved strength [31]. These findings indicated that supplementation was beneficial for increasing muscle strength in $1 \mathrm{RM}$ bench press but timing of ingestion was not important. The results on body composition may have had different effects if participants had consumed adequate $\mathrm{kcal}^{-1 g^{-1}}$, as greater-than-maintenancecaloric needs are required for muscular hypertrophy to occur. Strength did increase, providing evidence to both the effectiveness of protein supplementation on strength and the effectiveness of the workout regimen used in this study. Future studies should ensure that participants are consuming greater than $44-50 \mathrm{kcal}^{1} \mathrm{~kg}^{-1}$ to maximize muscle hypertrophy [9].

Hoffman et al. conducted a double-blind study focusing on the use of protein supplements to hasten recovery from acute resistance weight training sessions [32]. Fifteen strength-trained men were matched for strength then randomly assigned to receive $42 \mathrm{~g}$ of either a) a proprietary protein blend (enzymatically hydrolyzed collagen-, whey-, or casein-protein isolates, plus $250 \mathrm{mg}$ of additional BCAA pre and post workout), or b) a placebo of maltodextrin pre-and post-workout [32]. Participants initially performed a $1 \mathrm{RM}$ for squat, dead lift, and barbell lunge exercises. On the second visit, subjects performed four sets of at least 10 repetitions at $80 \%$ of their $1 \mathrm{RM}$ for the exercises with 90 seconds between sets. On visits three (24 hours from visit two) and four (48 hours from visit two), participants performed four sets of squats with the previous weight and performed as many repetitions per set as possible [32]. Hoffman et al. [32] found that the group receiving the proprietary protein blend performed significantly more repetitions at visits three and four than did subjects receiving the placebo. These findings provide evidence that protein supplementation pre- and post-workout is useful in maximizing weight-training performance, as well as in hastening exercise recovery 24 and 48 hours post-exercise.

Timing of supplementation in relation to the resistance workout also has been studied [33]. Cribb et al. assigned 23 male bodybuilders to one of two groups: those who received a supplement a) before and after a workout, or b) in the morning and evening. The supplement contained $40 \mathrm{~g}$ protein (from whey isolate), $43 \mathrm{~g}$ carbohydrate (glucose), and seven $\mathrm{g}$ creatine monohydrate per 100 g. Each participant was given the supplement in quantities of $1.0 \mathrm{~g} \mathrm{~kg}^{-1}$ body weight. All participants followed a preliminary resistance weight-training program for $8-12$ weeks before baseline measurements were taken. Participants then started the 10-week resistance weight-training session which was divided into three distinct stages: preparatory $(70-75 \% 1 \mathrm{RM})$, overload phase 1 (80-85\%1RM), and overload phase 2 (90-95\% 1RM) [33].

Results indicated significant differences in body composition in the group consuming the supplement preand post-workout [33]. This group experienced increased LBM and decreased body fat. Both groups demonstrated increases in strength, but the pre- and post-workout group demonstrated significantly greater gains [33], indicating that timing of the ingestion of the protein supplement was crucial. This is contradictory to the findings of Hoffman et al. [31] with respect to changes in body composition. This could be because Cribb et al. [33] used a supplement that was a combination of protein, carbohydrate and creatine whereas, Hoffman et al. [31] supplemented with protein only. The major finding of this study was that after 10 weeks of training, supplementation pre/post each workout resulted in greater improvements in 1RM strength and body composition (increased LBM and decreased body fat percentage) compared with a matched group who consumed supplement in the morning and evening, outside of the pre- and post-workout time frames.

The majority of studies of protein intake and resistance exercise have been conducted on younger adult males [31-33]. In contrast, Verdijk et al. investigated the impact of the protein, casein hydrolysate, on muscle hypertrophy in healthy untrained elderly men [34]. Researchers randomly assigned 28 elderly men to consume either a protein supplement or a placebo pre- and post-workout. Subjects performed a 12-week resistance weight-training program requiring weightlifting $3 \mathrm{~d} \mathrm{wk}^{-1}$. Baseline and ending measurements were obtained, including strength assessments, CT scans, DXA scans, blood samples, 24-hour urine samples, muscle biopsies, and immunohistochemistry tests. Results indicated no differences in ending measurements between the protein group and placebo group in muscle hypertrophy, strength, or body composition [34], suggesting that for elderly men, intake of $20 \mathrm{~g}$ casein hydrolysate before and after resistance training does not increase muscle hypertrophy or strength. In this study, however, only $20 \mathrm{~g}$ of casein was used, and it was divided into two servings. This protocol would not have provided participants with the required $3 \mathrm{~g}$ of leucine needed to maximize protein synthesis. Additionally, since casein is slow digesting [44,45], it may not have been ideal for use in a study of elderly men. 
Future studies with this population should incorporate whey protein, which is highly bioavailable in an amount that would provide at least $3 \mathrm{~g}$ leucine $[29,30]$. Studies comparing the effects of supplementation with adequate protein and those with creatine-enhanced protein pre-and post-workout also should be conducted to determine whether creatine is needed to produce the desired outcomes, as has been demonstrated in younger men [33] (See Table 2).

The long-term use of whey protein pre- and postresistance exercise was investigated by Hulmi et al. [35], by assigning participants to one of three groups:1) $15 \mathrm{~g}$ of whey protein before and after resistance exercise, 2) a placebo before and after resistance exercise, or 3) no supplement no participation in weightlifting but continued habitual exercise as they did prior to the study. Participants in the first two groups completed two resistance exercise sessions per week for 21 weeks consisting of both upper and lower body multi-joint lifts. All participants then had biopsies performed on their vastus lateralis. Results indicated that the whey protein group had significantly greater increases than the other groups in vastus lateralis hypertrophy, and greater overall muscle hypertrophy [35]. These findings provide evidence that whey protein supplementation pre- and post-workout is useful in increasing muscle hypertrophy.

Andersen et al. examined the effects of a mixed blend of proteins on muscle strength and muscle fiber size [36]. They studied the ingestion pre- and postworkout of $25 \mathrm{~g}$ of a protein blend (whey, casein, eggwhite proteins, and l-glutamine), compared with a maltodextrin supplement, over the course of a $3 \mathrm{~d}^{-1 k^{-1}}$ 14-week resistance-training program. Results of muscle biopsies from the vastus lateralis indicated that the protein supplementation group had greater increases in muscle hypertrophy and in squat jump height [36]. Results of this study provide evidence that supplementation with a blend of whey, casein, egg-white proteins, and l-glutamine pre- and post-workout helps promote muscle hypertrophy and improved physical performance.

\section{Training effects}

The effects of training protocols also are very important on increases in strength and muscle hypertrophy. All studies used in this review followed a resistance weight-lifting protocol [31-36,38-41]. It appears from the studies referenced in this review that a training protocol tailored for muscle hypertrophy and strength should be at least 10-12 weeks in length and involve three to five training sessions weekly, consisting of compound lifts that include both the upper and lower body $[31,33,35,36,38,40,41]$.

\section{Conclusions}

Researchers have tested the effects of types and timing of protein supplement ingestion on various physical changes in weightlifters. In general, protein supplementation pre- and/or post-workout increases physical performance [31-34,38-41], training session recovery [32], lean body mass [33,38-41], muscle hypertrophy [35,38-41], and strength $[31,33,38,40,41]$. Specific gains, however, differ based on protein type and amounts [31-36]. For example, whey protein studies showed increases in strength [31,33], whereas, supplementation with casein did not promote increases in strength [34]. Additional research is needed on the effects of a protein and creatine supplement consumed together, as one study has shown increases in strength and LBM [33].

Studies on timing of milk consumption have indicated that fat-free milk post-workout was effective in promoting increases in lean body mass, strength, muscle hypertrophy and decreases in body fat [38-41] Milk proteins have been shown to be superior to soy proteins in promoting lean body mass [38] and muscle mass development [39]. What is interesting about the milk studies [38-41] is that not one of them provided the 3-4 $\mathrm{g}$ of leucine needed to promote maximal MPS (See Table 2), yet they all showed improvements in LBM and strength. This raises the question of whether other components in milk could have contributed to the changes observed. Future researchers should investigate whether other properties of milk help increase LBM when leucine intake is suboptimal to provide maximal MPS. Researchers should also investigate the effects of protein supplements when participants are consuming adequate $\mathrm{kcal}^{-}$ $\mathrm{kg}^{-1}$ and $\mathrm{g} \mathrm{kg}^{-1}$ of protein to maximize muscle hypertrophy.

The effects of timing of ingestion of EAAs on physical changes following exercise also have been studied $[47,48]$. Tipton et al. [47] found that the ingestion of EAAs prior to resistance exercise was more beneficial than post-ingestion in promoting protein synthesis [47], but these results did not hold true with respect to whey protein ingestion [48]. Once a protein has been consumed by an individual, anabolism is increased for about three hours postprandial with a peak at about 45-90 minutes [14]. After about three hours postprandial, MPS drops back to baseline even though serum amino acid levels remain elevated [14]. These data show that there is a limited time window within which to induce protein synthesis before a refractory period begins. With this in mind, an ideal protein supplement after resistance exercise should contain whey protein, as this will rapidly digest and initiate MPS, and provide 3-4 g of leucine per serving, which is instrumental in promoting maximal MPS $[29,30]$. A combination of a fast-acting carbohydrate source such as maltodextrin or glucose should be 
consumed with the protein source, as leucine cannot modulate protein synthesis as effectively without the presence of insulin $[27,28]$ and studies using protein sources with a carbohydrate source tended to increase LBM more than did a protein source alone [33,37-41]. Such a supplement would be ideal for increasing muscle protein synthesis, resulting in increased muscle hypertrophy and strength. In contrast, the consumption of essential amino acids and dextrose appears to be most effective at evoking protein synthesis prior to rather than following resistance exercise [47]. To further enhance muscle hypertrophy and strength, a resistance weighttraining program of at least $10-12$ weeks $3-5 \mathrm{~d}^{-\mathrm{wk}^{-1}}$ with compound movements for both upper and lower body exercises should be followed [31,33,35,36,38,40,41].

\section{Abbreviations \\ ml: Milliliter; d: Day; g: Gram; kg: Kilogram; wk: Week; RDA: Recommended dietary allowance; LBM: Lean body mass; MPS: Maximal protein synthesis; 1RM: One-repetition maximum; DXA: Dual-energy X-ray absorptiometry; $\mathrm{CT}$ : Computed tomography; kcal.kg ${ }^{-1}$ : Kilocalories per kilogram; $9 . \mathrm{kg}^{-1}$ : Gram per kilogram; BCAA: Branched chain amino acids; EAA: Essential amino acids; Hr: Hour; methionyl-tRNA: Methionyl-transfer ribonucleic acid; 40S: Eukaryotic small ribosomal subunit; 43S: Pre-initiation complex; elF2: Eukaryotic initiation factor 2; mRNA: Messenger ribonucleic acid; GTP: Guanosine triphosphate; elF4F: Eukaryotic initiation factor 4F; elF4E: Eukaryotic initiation factor 4E; mTOR: Mammalian target of rapamycin; raptor: MTOR raptor; \\ Rheb: Rashomolog enriched in the brain; 4E-BP1: elF4E binding protein 1; S6K1: Ribosomal protein S6 kinase.}

\section{Competing interests}

The authors declare that they have no competing interests.

\section{Authors' contributions}

MS was the primary author of the manuscript. JL, AP and AS played an important role in manuscript preparation and revisions. All authors have read and approved the final manuscript.

\section{Author details}

'School of Family, Consumer, and Nutrition Sciences. Northern Illinois University, DeKalb, IL, USA. ${ }^{2}$ The Department of Kinesiology and Physical Education, Northern Illinois University, DeKalb, IL, USA.

Received: 25 July 2012 Accepted: 10 December 2012

Published: 14 December 2012

\section{References}

1. Lemon P: Effects of exercise on dietary protein requirements. Int I Sport Nutr 1998, 8:426-447.

2. Lemon PW, Proctor DN: Protein intake and athletic performance. Sports Med 1991, 12:313-325.

3. Kreider R: Effects of protein and amino acid supplementation on athletic performance. Sportscience 1999, 3(1). sportsci.org/jour/9901/rbk.html.

4. Phillips SM: Protein requirements and supplementation in strength sports. Nutrition 2004, 20:689-695.

5. Lemon PW: Beyond the zone: protein needs of active individuals. J Am Coll Nutr 2000, 19(Suppl):513S-521S.

6. Lemon PW: Protein requirements of strength athletes. In Sports Supplements. Edited by Antonio J, Stout J. Philadelphia, PA: Lippincott, Williams, \& Wilkins Publishing Co; 1996.

7. Campbell B, Kreider R, Ziegenfuss T, Bounty P, Roberts M, Burke D, Landis J, Lopez $\mathrm{H}$, Antonio J: International society of sports nutrition position stand: protein and exercise. J Int Soc Sports Nutr 2007, Available at: http://www.jissn.com/content/4/1/8.

8. Gropper S, Smith J, Groff J: Protein. In Advanced Nutrition and Human Metabolism. 5th edition. California: Wadsworth Cengage Learning; 2009:179-250
9. American Dietetic Association, Dietitians of Canada, \& American College of Sports Medicine: Position stand: nutrition and athletic performance. Med Sci Sports Exerc 2000, 32:2130-2145.

10. Kimball SR, Jefferson LS: New functions for amino acids: effects on gene transcription and translation. Am J Clin Nutr 2006, 83:500S-507S.

11. Anthony JC, Anthony TG, Kimball SR, Vary TC, Jefferson LS: Orally administered leucine stimulates protein synthesis in skeletal muscle of postabsorptive rats in association with increased elF4F formation. J Nutr 2000, 130:139-145.

12. Anthony JC, Yoshizawa F, Anthony TG, Vary TC, Jefferson LS, Kimball SR: Leucine stimulates translation initiation in skeletal muscle of postabsorptive rats via a rapamycin-sensitive pathway. J Nutr 2000, 130:2413-2419.

13. Norton L, Layman D, Garlick P: Isonitrogenous protein sources with different leucine contents differentially effect translation initiation and protein synthesis in skeletal muscle. FASEB J 2008, 22:869-875.

14. Norton L, Layman D, Bunpo P, Anthony T, Brana D, Garlick P: The Leucine content of complete meal directs peak activation but not duration of skeletal muscle protein synthesis and mammalian target of rapamycin signaling in rats. J Nutr 2009, 139(6):1103-1109.

15. Dreyer H, Drummond, Pennings B, Fuijta S, Glynn E, Chinkes D, Dhanani S, Volpi E, Rasmussen B: Leucine-enriched essential amino acid and carbohydrate ingestion following resistance exercise enhances mTOR signaling and protein synthesis in human muscle. Am J Physiol Endocrinol Metab 2008, 294:E392-E400.

16. Stipanuk M: Leucine and protein synthesis: mTOR and beyond. Nutr Rev 2007, 65(3):122-129.

17. Norton L, Layman D: Leucine regulates translation initiation of protein synthesis in skeletal muscle after exercise. J Nutr 2006, 136:533S-537S.

18. Crozier S, Kimball S, Emmert S, Anthony J, Jefferson L: Oral leucine administration stimulates protein synthesis in rat skeletal muscle. J Nutr 2005, 135:376-382.

19. Hara K, Maruki Y, Long X, Yoshino K-I, Oshiro N, Hidayat S, Tokunaga C, Avruch J, Yonezawa K: Raptor, a binding partner of target of rapamycin (mTOR), mediates TOR action. Cell 2002, 110:177-189.

20. Kim D, Sarbassov D, Ali SM, King J, Latek R, Erdjument-Bromage $H$, Tempst P, Sabatini D: mTOR interacts with raptor to form a nutrientsensitive complex that signals to the cell growth machinery. Cell 2002, 110:163-175.

21. Atherton PJ, Babraj J, Smith K, Singh J, Rennie MJ, Wackerhage H: Selective activation of AMPK-PGC-1_ or PKB-TSC2-mTOR signaling can explain specific adaptive responses to endurance or resistance training like electrical muscle stimulation. FASEB J 2005, 19:786-788.

22. Baar K, Esser K: Phosphorylation of p7056k correlates with increased skeletal muscle mass following resistance exercise. Am J Physiol Cell Physiol 1999, 276:C120-C127.

23. Koopman R, Wagenmakers A, Manders R, Zorenc A, Senden J, Gorselink M, Keizer H, Loon C: Combined ingestion of protein and free leucine with carbohydrate increases postexercise muscle protein synthesis in vivo in male subjects. Am J Physiol Endocrinol Metab 2005, 288:E645-E653.

24. Fulks RM, Li JB, Goldberg AL: Effects of insulin, glucose, and amino acids on protein turnover in rat diaphragm. J Biol Chem 1975, 250:290-298.

25. Li JB, Jefferson LS: Influence of amino acid availability on protein turnover in perfused skeletal muscle. Biochim Biophys Acta 1978, 544:351-359.

26. Buse MG, Reid SS: Leucine, a possible regulator of protein turnover in muscle. J Clin Invest 1975, 56:1250-1261.

27. Byfield MP, Murray JT, Backer JM: hVps34 is a nutrient-regulated lipid kinase required for activation of p70 S6 kinase. J Biol Chem 2005, 280:33076-33082.

28. Nobukuni T, Joaquin M, Roccio M, Dann SG, Kim SY, Gulati P, Byfield MP, Backer JM, Natt F, Bos JL, Zwartkruis FJ, Thomas G: Amino acids mediate $\mathrm{mTOR} /$ raptor signaling through activation of class 3 phosphatidylinositol 3OH-kinase. Proc Natl Acad Sci USA 2005, 102:14238-14243.

29. Paddon-Jones D, Sheffield-Moore M, Zhang X, Volpi E, Wolf S, Aarsland A, Ferrando A, Wolfe R: Amino acid ingestion improves muscle protein synthesis in the young and elderly. Am J Physiol Endocrinol Metab 2004, 286:E321-E328.

30. Tipton K, Ferrando A, Phillips S, Doyle D, Wolfe R: Postexercise net protein synthesis in human muscle from orally administered amino acids. Am J Physiol 1999, 276:E628-E634. 
31. Hoffman J, Ratamess N, Tranchina C, Rashti S, Faigenbaum A: Effect of protein-supplement timing on strength, power, and body-composition changes in resistance-trained men. Int I Sport Nutr Exerc Metab 2009, 19(2):172-185.

32. Hoffman J, Ratamess N, Tranchina C, Rashti S, Kang J, Fiagenbaum A: Effects of a proprietary protein supplement on recovery indices following resistance exercise in strength/power athletes. Amino Acids 2010, 38:771-778.

33. Cribb $P$, Hayes A: Effects of supplement timing and resistance exercise on skeletal muscle hypertrophy. Med Sci Sports Exerc 2006, 38(11):1918-1925.

34. Verdijk L, Jonkers R, Gleeson B: Protein supplementation before and after exercise does not further augment skeletal muscle hypertrophy after resistance training in elderly men. Am J Clin Nutr 2009, 89(2):608-616.

35. Hulmi J, Koyanen V, Selanne H, Kraemer W, Hakkinen K, Mero A: Acute and long-term effects of resistance exercise with or without protein ingestion on muscle hypertrophy and gene expression. Amino Acids 2009, 37:297-308

36. Andersen L, Tufekovic G, Zebis M, Crameri R, Verlaan G, Kjaer M, Suetta C, Magnusson P, Aagaard P: The effect of resistance training combined with timed ingestion of protein on muscle fiber size and muscle strength. Metabolism 2005, 54:151-156.

37. Elliot T, Cree M, Sanford A, Wolfe R, Tipton K: Milk ingestion stimulates net muscle protein synthesis following resistance exercise. Med Sci Sports Exerc 2006, 38(4):667-674.

38. Hartman J, Tang J, Wilkinson S, Tarnopolsky M, Lawrence R, Fullerton A, Phillips $\mathrm{S}$ : Consumption of fat-free fluid milk after resistance exercise promotes greater lean mass accretion than does consumption of soy or carbohydrate in young, novice, male weightlifters. Am J Clin Nutr 2007, 86(2):373-381.

39. Wilkinson S, Tarnopolsky M, MacDonald M, MacDonald J, Armstrong D, Phillips S: Consumption of fluid skim milk promotes greater muscle protein accretion after resistance exercise than does consumption of an isonitrogenous and isoenergetic soy-protein beverage. Am J Clin Nutr 2007, 85(4):1031-1040.

40. Rankin J, Goldman L, Puglisi M, Nickols-Richardson S, Earthman C, Gwazdauskas F: Effect of post-exercise supplement consumption on adaptations to resistance training. J Am Coll Nutr 2004, 4(23):322-330.

41. Josse A, Tang J, Tarnopolsky M, Phillips S: Body composition and strength changes in women with milk and resistance exercise. Med Sci Sports Exerc 2010, 42(6):1122-1130

42. Tang J, Moore D, Kujbida G, Tarnopolsky M, Phillips S: Ingestion of whey hydrolysate, casein, or soy protein isolate: effects on mixed muscle protein synthesis at rest and following resistance exercise in young men. J Appl Physiol 2009, 107(3):987-992.

43. Norton L, Wilson G, Layman D, Moulton C, Garlick P: Ingestion of whey hydrolysate, casein, or soy protein isolate: effects on mixed muscle protein synthesis at rest and following resistance exercise in young men. Nutr Metab 2012, 9:67.

44. Hoffman J, Falvo M: Protein—which is best? J Sports Sci Med 2004, 3:118-130.

45. Boirie $Y$, Dangin M, Gachon P, Vasson MP, Maubois JL, Beaufrere B: Slow and fast dietary proteins differently modulate postprandial accretion. Proc Natl Acad Sci 1997, 94:14930-14935.

46. Tipton K, Elliot T, Cree M, Wolf S, Sanford A, Wolfe R: Ingestion of casein and whey proteins result in muscle anabolism after resistance exercise. Med. Sci. Sports Exerc 2004, 36:2073-2081.

47. Tipton KD, Rasmussen BB, Miller SL, Wolf SE, Owens-Stovall SK, Petrini BE, Wolfe RR: Timing of amino acid-carbohydrate ingestion alters anabolic response of muscle to resistance exercise. Am J Physiol Endocrinol Metab 2001, 281:E197-E206.

48. Tipton K, Elliott T, Cree M, Aarsland A, Sanford A, Wolfe R: Stimulation of net muscle protein synthesis by whey protein ingestion before and after exercise. Am J Physiol Endocrinol Metab 2007, 292:E71-E76.

\section{doi:10.1186/1550-2783-9-54}

Cite this article as: Stark et al.: Protein timing and its effects on muscular hypertrophy and strength in individuals engaged in weighttraining. Journal of the International Society of Sports Nutrition 2012 9:54 